\title{
Fascia as a Proprioceptive Organ and its Role in Chronic Pain - a Review of Current Literature
}

\author{
Cornelia Kopeinig, Barbara Gödl-Purrer ${ }^{*}$, Beate Salchinger \\ From Safety in hospitals: from strategy to implementation Annual Scientific Meeting 2015 \\ Graz, Austria. 29-30 September 2015
}

\section{Background}

Latest research shows that the fascia is highly innervated. Especially the thoracolumbar fascia exhibits a high density of mechanoreceptors [1]. They are responsible for afferent proprioceptive information, i.e. implicit information about joint position and movement. In chronic pain patients, proprioception is impaired and studies indicate that connective tissue structures in painful body parts exhibit pathological changes. Thus, a hypothetical connection between the chronification of pain and proprioceptive deficits exists. This should be considered when treating chronic pain [2]. So far, the connection between fascial and proprioceptive dysfunctions has not been elaborated from a physiotherapeutic point of view, even though fascia and its proprioceptive ability could explain the working mechanisms behind physiotherapeutic methods such as manual therapy $[3,4]$.

\section{Objectives}

Which proprioceptive abilities of fascia are relevant for physiotherapeutic clinical reasoning and treatment of chronic pain?

\section{Material and methods}

Literature search was performed via Medline, Pubmed, CINAHL, PeDro. Data extraction followed the Consort criteria in its latest version.

\section{Results}

The thoracolumbar fascia is densely innervated with mechanoreceptors, which fulfill an important task in proprioceptive processing. Besides the finding that the thoracolumbar fascia is pathologically altered in a low back pain population, this population displays proprioceptive

\footnotetext{
* Correspondence: Barbara.goedl-purrer@fh-joanneum.at Institute of Physiotherapy, FH JOANNEUM, University of Applied Sciences,
} Graz, Austria deficits, measured with joint positioning sense and twopoint discrimination, too [2,5]. Fascia should therefore be considered a cause of pain and proprioceptive deficits and treatment should be applied accordingly. Manual therapy could be used to regain proprioceptive acuity in the region of pain. The passive movement with different frequencies, amplitudes and intensities stimulates fascial tissue and the mechanoreceptors. Through this stimulation, additional proprioceptive input is generated, which could lead to altered central processing. This in turn leads to tonus regulation and better performance in proprioceptive assessments [5]. Therapists should include this effect in their clinical reasoning in order to apply more specific treatments.

\section{Conclusions}

The impact of physiotherapeutic treatment on fascia could establish a completely new perspective in clinical reasoning and therapy. Only few studies exist on proprioceptive deficits, their assessment and treatment in relation to pain. Further research is required, since the proprioceptive properties of fascia could be an integral part in explaining chronification mechanisms of pain as well as therapy methods; how they are applied and the underlying mechanisms involved.

\section{Competing interests \\ There are no competing interests.}

Published: 30 October 2015

\section{References} thoracolumbar fascia in rats and humans. Neuroscience 2011, 194:302-308.
. Tesarz J, Hoheisel U, Wiedenhöfer B, Mense S: Sensory innervation of the 
2. Langevin HM, Tuttle-Stevens D, Fox JR, Badger GJ, Bouffard NA, Krag MH, Wu J, Henry SM: Ultrasound evidence of altered lumbar connective tissue structure in human subjects with chronic low back pain. $B M C$ Musculoskeletal Disorders 2009, 10:151-160.

3. Schleip R: Fascial plasticity - a new neurobiological explanation: Part 1. Journal of Bodywork \& Movement Therapies 2003a, 7(1):1-9.

4. Schleip R: Fascial plasticity - a new neurobiological explanation: Part 2. Journal of Bodywork \& Movement Therapies 2003a, 7(2):104-116, (2003b).

5. Simmonds N, Miller $\mathrm{P}$, Gemmel $\mathrm{H}$ : A theoretical framework for the role of fascia in manual therapy. Journal of Bodywork \& Movement Therapies 2010, 16:83-93.

doi:10.1186/2056-5917-1-S1-A2

Cite this article as: Kopeinig et al:: Fascia as a Proprioceptive Organ and its Role in Chronic Pain - a Review of Current Literature. Safety in Health 2015 1(Suppl 1):A2.

\section{Submit your next manuscript to BioMed Central} and take full advantage of:

- Convenient online submission

- Thorough peer review

- No space constraints or color figure charges

- Immediate publication on acceptance

- Inclusion in PubMed, CAS, Scopus and Google Scholar

- Research which is freely available for redistribution

Submit your manuscript at www.biomedcentral.com/submit 